\section{Comparison of intravenous and aerosol salbutamol}

Aerosol salbutamol has a prolonged bronchodilator effect ${ }^{1}$ and is more potent than an equal intravenous dose. ${ }^{2}$ We have studied both routes of administration in asthmatic patients to compare their length of action.

\section{Patients, methods, and results}

Five patients with well controlled asthma were studied. Their asthma showed no significant diurnal variation. All were being treated with salbu tamol by regular inhalation, and three took prednisone. They were studied on two consecutive mornings, having stopped bronchodilator drugs for 12 hours.

Recordings were made of $\mathrm{FEV}_{1}$ and forced vital capacity (FVC) with a Vitalograph dry spirometer. Peak expiratory flow rate (PEFR) was measured with a Wright peak flow meter. Radial pulse rate was measured manually.

On the first day, after consistent baseline readings were obtained, al patients received $250 \mu \mathrm{g}$ salbutamol intravenously over 3 minutes. Pulse rate was recorded immediately and all measurements were made 5, 10, and 15 minutes following intravenous injection and then repeated at 15-minute intervals to 90 minutes and at 30 -minute intervals to 240 minutes. Aerosol salbutamol was then given from a pressurised aerosol in $100 \mu \mathrm{g}$ doses at 5 -minute intervals to estimate the cumulative dose required to produce an equivalent increase in $\mathrm{FEV}_{1}$ to the intravenous dose.

On the second day this equivalent dose of aerosol salbutamol was given in $100 \mu \mathrm{g}$ increments over 3 minutes followed by the same protocol of measurements.

Four patients required $200 \mu \mathrm{g}$ aerosol salbutamol and one needed $100 \mu \mathrm{g}$ to produce the same immediate increase in $\mathrm{FEV}_{1}$ as $250 \mu \mathrm{g}$ intravenous salbutamol. The table shows the mean increases ( \pm standard error) in FEV for the two preparations; curves drawn for individual patients conformed to the mean pattern. Similar curves were obtained for PEFR and FVC. The peak response was not significantly different, but the aerosol bronchodilatation declined more slowly. Student's paired $t$ test showed a significant difference between the means from 45 to 210 minutes $(P<0.05)$, which was more significant at 120 minutes $(P<0.01)$. The differences were not significant $(\mathrm{P}<0 \cdot 1)$ for PEFR over similar periods or for FVC. Pulse rate increased by a mean 20 beats $\min ^{-1}$ after intravenous salbutamol; no increase was detected after the aerosol.

Mean ( \pm standard error) percentage changes in FEV $V_{1}$ in five patients after $250 \mu \mathrm{g}$ salbutamol intravenously and 100-200 $\mu \mathrm{g}$ by aerosol observed over 240 minutes

\begin{tabular}{|c|c|c|c|c|}
\hline \multirow{2}{*}{$\begin{array}{c}\text { Time } \\
\text { (minutes) }\end{array}$} & \multicolumn{2}{|c|}{ Intravenous } & \multicolumn{2}{|c|}{ Aerosol } \\
\hline & $\begin{array}{l}\text { Mean " } \\
\text { change FEV }\end{array}$ & $\begin{array}{l}\text { Standard } \\
\text { error }\end{array}$ & $\begin{array}{c}\text { Mean }{ }^{\circ} \\
\text { change FEV }\end{array}$ & $\begin{array}{c}\text { Standard } \\
\text { error }\end{array}$ \\
\hline $\begin{array}{r}0 \\
5 \\
10 \\
15 \\
30 \\
45 \\
60 \\
75 \\
90 \\
120 \\
150 \\
180 \\
210 \\
240\end{array}$ & $\begin{array}{c}0 \\
44 \cdot 8 \\
47 \cdot 0 \\
43 \cdot 8 \\
32 \cdot 6 \\
33.8 \\
32 \cdot 2 \\
23 \cdot 1 \\
26.9 \\
18.6 \\
15.8 \\
9.4 \\
4.5 \\
1.3\end{array}$ & $\begin{array}{r}10.2 \\
9.7 \\
10.8 \\
8.8 \\
11.3 \\
14.0 \\
9.4 \\
8.9 \\
4.9 \\
5.8 \\
2.7 \\
2.0 \\
1.3\end{array}$ & $\begin{array}{c}0 \\
44 \cdot 6 \\
47 \cdot 4 \\
51 \cdot 5 \\
48 \cdot 4 \\
48 \cdot 4 \\
43 \cdot 5 \\
43 \cdot 7 \\
41 \cdot 0 \\
34 \cdot 9 \\
33 \cdot 5 \\
21 \cdot 9 \\
20 \cdot 1 \\
7 \cdot 6\end{array}$ & $\begin{array}{r}15.4 \\
14.3 \\
12.9 \\
12.0 \\
13.8 \\
14.8 \\
14.3 \\
9.3 \\
5.5 \\
7.1 \\
5.6 \\
5.9 \\
2.2\end{array}$ \\
\hline
\end{tabular}

\section{Discussion}

Aerosol salbutamol might be expected to achieve higher surface concentrations in bronchial mucosa and smooth muscle than an equal intravenous dose and thus have a greater bronchodilator effect. ${ }^{2}$ However, when we deliberately lowered the aerosol dose to produce an equivalent increase in $\mathrm{FEV}_{1}$ and, therefore, presumably an equivalent stimulation of beta ${ }_{2}$-receptors, the aerosol showed a more prolonged bronchodilator effect. The discrepancy between these two routes is even greater when one appreciates that only a fraction of an inhaled aerosol reaches the bronchi. ${ }^{3}{ }^{4}$ This suggests that a very small dose is required for bronchodilator activity, which is most economically achieved by the aerosol route.

The prolonged bronchodilatation provided by very small doses of aerosol salbutamol was also a striking finding and may result either from its slow removal from bronchial epithelium or because inhibition of mediator release $\mathrm{e}^{5}$ augments its bronchodilator effect by this route.
Further studies of the rate of removal of salbutamol from the human lung should resolve this question.

The results also have a clinical message. For ambulant patients the aerosol route is very potent, minimises side effects, and lasts longer than intravenous injection. It is important to see if this also applies to acute severe asthma, when parenteral bronchodilators are often used in preference to the aerosol route. It needs to be established which route is best for this common medical emergency.

${ }^{1}$ Kennedy, M C S, and Simpson, W T, British fournal of Diseases of the Chest, 1969, 63, 165.

2 Spiro, S G, et al, Thorax, 1975, 30, 236.

${ }^{3}$ Palmes, E D, et al, fournal of Applied Physiology, 1973, 34, 356.

4 Symposium on isoproterenol therapy in asthma, Annals of Allergy, 1973 31, 1 .

${ }^{5}$ Assem, E S K, and Schild, M O, Nature, 1969, 224, 1028.

Brompton Hospital, London SW3 6HP

M R HETZEL, MB, MRCP, research assistant

T J H CLARK, MD, FRCP, consultant physician

\section{Hypertransaminasaemia with heparin treatment: effect of regular haemodialysis}

Sonnenblick et $a l^{1}$ reported that chronic heparin treatment (10 000 units intravenously every six hours for 10-21 days) increased serum aspartate aminotransferase (SGOT) and alanine aminotransferase (SGPT) activities by about $500 \%$. This might cause confusion in the differential diagnosis of pulmonary infarction, myocardial infarction, or liver disease in patients treated with heparin. Since this confusion might also extend to patients undergoing regular haemodialysis, where heparin treatment is routine, it is important to know whether heparin will induce an increase in the serum activities of these enzymes in such patients. An increase in SGPT activity may be an early sign of hepatitis and so the action of heparin on this enzyme's activity must be closely defined in all patients undergoing regular haemodialysis.

\section{Patients, methods, and results}

SGPT was measured by the Technicon SMA $12 / 60$ method in 19 patients with chronic renal failure before, during, and at the end of routine haemodialysis. Patients had been maintained on either a Meltec $1.5 \mathrm{~m}^{2}$ multipoint four hours three times a week or a Meltec $1.0 \mathrm{~m}^{2}$ multipoint six hours three times a week for one to 41 months. The heparin regimen (Heparin BP) was either a bolus of 5000 units with supplementary infusions of 1000 units hourly (total dose 10000 units) or simply 9000 units at the beginning of dialysis.

The results are shown in the table. The normal range for our laboratory is 8-47 IU/1. There were no significant differences (on the paired $t$ test) between the values at different times.

Mean SGPT values at various stages during haemodialysis

\begin{tabular}{|c|c|c|c|c|}
\hline & $\begin{array}{l}\text { Before } \\
\text { dialysis }\end{array}$ & 2 hours & 4 hours & 6 hours \\
\hline $\begin{array}{l}\text { No of patients } \\
\text { Geometric mean (IU/1) } \\
95 \% \text { confidence limits (IU/1) }\end{array}$ & $\begin{array}{c}19 \\
22 \cdot 9 \\
10-53\end{array}$ & $\begin{array}{c}19 \\
21 \cdot 9 \\
10-50\end{array}$ & $\begin{array}{c}19 \\
22 \cdot 3 \\
10-52\end{array}$ & $\begin{array}{c}10 \\
20 \cdot 6 \\
10-42\end{array}$ \\
\hline
\end{tabular}

\section{Comment}

These results indicate that routine heparin treatment during standard haemodialysis three times a week caused no significant acute change in the SGPT activity. Moreover, the range of SGPT values was not significantly different from that of the normal population, suggesting that chronic, intermittent heparin treatment does not cause 
a sustained increase in SGPT activity. These findings confirm that SGPT can be used in the early diagnosis of hepatitis in patients on a chronic haemodialysis and heparin regimen.

We thank Drs A M Davison and R B Payne for their advice and $\mathrm{Mr} M$ Smith for technical help. G S Walker is supported by the Yorkshire Kidney Research Fund.

${ }^{1}$ Sonnenblick, M, Oren, A, and Jacobsohn, W, British Medical fournal, $1975,3,77$.

Departments of Chemical Pathology and Renal Medicine, St James's (University) Hospital, Leeds LS9 7TF

J G SALWAY, PHD, senior biochemist

G S WALKER, BSC, MRCP, research fellow

\section{Serum ferritin levels in beta-thalassaemia trait}

Both iron deficiency and iron overload have been described in subjects with $\beta$-thalassaemia trait. ${ }^{12}$ In all these studies iron status has been assessed by peripheral blood count, serum iron, and by visual quantitation of bone marrow iron stores.Serum ferritin concentrations reflect iron storage status in health and also in certain diseases. ${ }^{3}$ We have measured the concentration of serum ferritin in 69 patients with $\beta$-thalassaemia trait and compared it with the concentration in normal adult control subjects.

\section{Patients, methods, and results}

Fifty female (of whom eight were pregnant) and 19 male patients of Mediterranean or Middle Eastern origin were studied. All were apparently

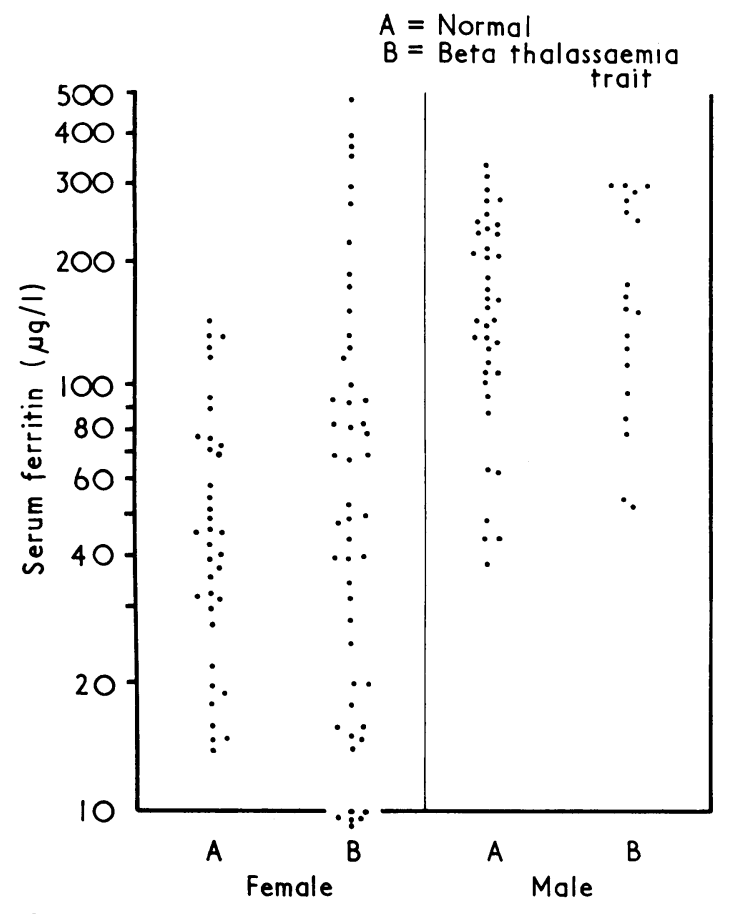

Serum ferritin levels in normal subjects and in patients with $\beta$-thalassaemia trait. otherwise healthy adults with an age range of 18 to 69 years. Only one woman was older than 60 . At the time of these studies 10 female patients were taking oral iron therapy, eight of them being pregnant.

The results were compared with those in 76 normal, healthy adult people ( 37 female and 39 male) whose ages ranged from 17-60. These people showed normal haemoglobin concentrations and normal red cell indices. None of the control patients was pregnant and none was taking iron.

The mean $\mathrm{Hb}, \mathrm{MCV}$, and $\mathrm{MCH}$ in normal females were as follows, the figures after the \pm sign representing 2 standard deviations, $13 \cdot 2 \mathrm{~g} / \mathrm{dl} \pm 1 \cdot 6$, $85 \cdot 2 \mathrm{fl} \pm 8 \cdot 8$, and $29 \cdot 5 \mathrm{pg} \pm 2 \cdot 8$, and in normal males $14 \cdot 8 \mathrm{~g} / \mathrm{dl} \pm 1 \cdot 0,85 \cdot 3 \mathrm{fl} \pm 6$, and $29.7 \mathrm{pg} \pm 1.4$ respectively. The mean haemoglobin concentration in the 50 female patients was $10.9 \mathrm{~g} / \mathrm{dl}+2.2$ and in the male patients was $12.6 \mathrm{~g} / \mathrm{dl}$ \pm 1.9 . Forty $\left(80^{\circ}{ }_{0}\right)$ of the female patients were anaemic $(\mathrm{Hb}<11.5 \mathrm{~g} / \mathrm{dl})$ and $16(88 \%)$ of the male patients were anaemic $(\mathrm{Hb}<13.5 \mathrm{~g} / \mathrm{dl})$. The mean $\mathrm{MCV}$ and $\mathrm{MCH}$ in the female patients were $64.8 \mathrm{fl} \pm 10.8$ and $21.1 \mathrm{pg} \pm 3.5$ respectively. The mean $\mathrm{MCV}$ in male patients was $63.6 \mathrm{fl} \pm 8.0$ and the $\mathrm{MCH}$ $20.8 \mathrm{pg}+2.5$. The haemoglobin $\mathrm{A}_{2}$ level was above $3.5 \%$ (our normal range $1 \cdot 5-3 \cdot 4 \%$ ) in all the 69 patients except one female, who had a haemoglobin $\mathrm{A}_{2}$ of $3.4 \%$ and was subsequently shown to be iron deficient.

The mean serum ferritin in the 37 normal adult females was $55.9 \mu \mathrm{g} / \mathrm{l}$ (range 14-148 $\mu \mathrm{g} / \mathrm{l}$ ) and in the 39 normal adult males $165.4 \mu \mathrm{g} / 1$ (range $39-340 \mu \mathrm{g} / \mathrm{l})$. The mean serum ferritin level in the 50 female patients $(97 \cdot 9$ $\mu \mathrm{g} / \mathrm{l}$, range $7-484 \mu \mathrm{g} / \mathrm{l}$ ) was greater than the mean of the control female patients, but the difference was not statistically significant. Nine female patients showed serum ferritin levels above the control range; three of the nine were taking iron at the time of this examination. Six female patients showed serum ferritin levels below $14 \mu \mathrm{g} / \mathrm{l}$, and four of these had a transferrin saturation of less than $16 \%$. None of the patients with subnormal serum ferritin levels was pregnant at the time of these studies.

All the male patients showed serum ferritin levels in the normal range (figure), and their mean serum ferritin level $(177 \mu \mathrm{g} / 1$, range 53-300 $\mu \mathrm{g} / 1)$ was not significantly different from that of the control subjects. None of the male patients was taking iron therapy. In neither sex was there a relation between serum ferritin and age or percentage saturation of serum iron binding capacity.

\section{Discussion}

The results here show that patients with uncomplicated $\beta$ thalassaemia trait in general have normal iron stores. This finding is consistent with the observation that iron absorption is normal in $\beta$-thalassaemia trait. ${ }^{4}$

Most of our female patients had received oral iron therapy during their pregnancies, often intensively before the diagnosis of $\beta$ thalassaemia trait had been made. $A_{2}$ least four of the patients with high serum ferritin levels studied here had been given oral iron for long periods or intramuscular iron, and it is likely that oral iron therapy accounts for the increased iron stores, assessed by serum ferritin assay, in the other five patients with raised levels.

The male patients perhaps form a better group to compare iron status of $\beta$-thalassaemia trait with normal, since men are less likely to have blood tests or to be given iron therapy. Indeed, as far as we could be sure only one of the males had had iron therapy. The serum ferritin levels in all the male patients were normal.

The results of this study show, therefore, that iron status of patients with $\beta$-thalassaemia trait is normal, that these patients may become iron deficient with an equal frequency to normal subjects, and that serum ferritin estimation is of value to diagnose coincidental iron deficiency in $\beta$-thalassaemia trait.

${ }^{1}$ Fleming, A F, and Lynch, W, Fournal of Obstetrics and Gynaecology of the British Commonwealth, 1969, 76, 451.

${ }^{2}$ Hedge, U M, et al, British Medical fournal, 1975, 3, 509.

3 Jacobs, A, and Worwood, M, New England fournal of Medicine, 1975, 292, 951.

${ }^{4}$ Bannerman, R M, et al, British Fournal of Haematology, 1964, 10, 490.

Department of Haematology, Royal Free Hospital, London NW3 2QG

SONAY HUSSEIN, MD, lecturer

A V HOFFBRAND, FRCP, MRCPATH, professor

MARTINE LAULICHT, technician

Department of Haematology, North Middlesex Hospital, London N18

B ATTOCK, MB, MRCPATH, senior registrar

Department of Haematology, Hospital for Sick Children, London WC1

ELIZABETH LETSKY, MB, MRCPATH, lecturer 